\title{
Deoxyribonucleic Acid Homologies Among Strains of Bacillus sphaericus
}

\author{
VIRGINIA K. KRYCH, ${ }^{1}$ JOHN L. JOHNSON, ${ }^{2}$ AND ALLAN A. YOUSTEN ${ }^{1}$ \\ Microbiology Section, Biology Department, ${ }^{1}$ and Anaerobe Laboratory, ${ }^{2}$ Virginia Polytechnic Institute and \\ State University, Blacksburg, Virginia 24061
}

The genetic relatedness of 62 strains of Bacillus sphaericus, 4 strains of $B$. pasteurii, 6 strains of $B$. brevis, and 1 strain each of $B$. globisporus and $B$. aminovorans was examined by deoxyribonucleic acid (DNA) homology. Five homology groups were identified, and they contained all but 12 of the $B$. sphaericus strains. Intergroup homologies ranged from about 20 to $40 \%$ except for groups III and IV, which had 50 to $60 \%$ intergroup homology. Although a few strains within some groups had 63 to $69 \%$ homology to the reference strain, most strains were in the 70 to $90 \%$ range. Homology group I contained the type of strain of B. sphaericus, ATCC 14577, and three other strains. Homology group II was subdivided into groups IIA and IIB, the former containing all of the strains found to be pathogenic for mosquito larvae. Although none of the physiological characteristics or combination of characteristics examined allowed the complete differentiation of strains into the appropriate homology groups, the strains of group I could be distinguished from those of group IIA-IIB. The strains of group IIA could be distinguished from all others by mosquito pathogenicity. The $B$. pasteurii strains formed a distinct homology group, although the guanine plus cystosine contents of their DNAs fell within the range of 34 to $37 \mathrm{~mol} \%$ found for the 45 strains of $B$. sphaericus examined for this property. The $B$. brevis strains possessed a higher guanine plus cystosine content, and their DNAs were unrelated to the DNAs of the $B$. sphaericus reference strains tested.

Although Bacillus sphaericus has been studied by a number of workers since its original description by Neide in 1904 (19), the boundaries around this species continue to be "diffuse and arbitrary" (9). Most efforts to clarify its taxonomic position have depended heavily upon the shape and position of the spore in the sporangium, a few nutritional characteristics, the inability to ferment a number of sugars, deamination of phenylalanine, growth in broth supplemented with $7 \% \mathrm{NaCl}$ or lysozyme, decomposition of tyrosine, and production of urease $(2,3$, $6,8,10,15,23)$. The distinction between $B$. latter has been characterized by its high level of urease activity and by a growth requirement for urea or ammonia in an alkaline medium $(8,9$, 10). Many strains of $B$. sphaericus are also urease positive. $B$. loehnisii has been proposed to include intermediate strains which do not complete the decomposition of $2 \%$ urea in $48 \mathrm{~h}$ and which are less dependent than $B$. pasteurii on ammonia in an alkaline medium (8). In addition, there are some less-well-known species such as $B$. globisporus and $B$. aminovorans which are similar to $B$. sphaericus but which have slightly different biochemical properties or temperature ranges for growth.
The possibility of human pathogenicity among strains of $B$. sphaericus has been raised by the reports of Allen and Wilkinson (1) and Farrar (7). Pathogenicity for mosquito larvae has also been shown $(14,22)$, although it is unknown how widespread either human or mosquito larval pathogenicity is among strains of the species.

In the investigation reported here, we examined the relationships among strains of $B$. sphaericus and their relationship to some similar species. This has involved the determination of the guanine plus cystosine $(\mathrm{G}+\mathrm{C})$ content of the deoxyribonucleic acid (DNA) and the DNA homology among the strains. In addition, the strains were tested for their pathogenicity to mosquito larvae.

\section{MATERIALS AND METHODS}

Bacterial strains. The bacterial strains used in this study and their sources are listed in Table 1.

Media and growth conditions. All of the strains were grown in nutrient broth (Difco) supplemented with $0.05 \%$ yeast extract (Difco), $5 \times 10^{-5} \mathrm{M} \mathrm{MnCl}_{2}, 7$ $\times 10^{-4} \mathrm{M} \mathrm{CaCl}_{2}$, and $10^{-3} \mathrm{M} \mathrm{MgCl}_{2}$ (NYSM). For growth of $B$. pasteurii, NYSM broth was supplemented with $2.0 \%$ urea before autoclaving. Cells used as an inoculum were grown in static tubes of NYSM 
TABLE 1. Strains used in the study

\begin{tabular}{|c|c|}
\hline Strain & Source \\
\hline \multicolumn{2}{|l|}{ B. sphaericus } \\
\hline ATCC 14577 & 1,3 \\
\hline ATCC 10208 & 1,2 \\
\hline NRS 967 & 1,2 \\
\hline NCTC 9602 & Dr. Tipper, University of Mass \\
\hline 1593 & 3; Mosquito larvae, Indonesia \\
\hline SSII-1 & 3; Mosquito larvae, India \\
\hline 1404 & 3; Mosquito larvae, Philippines \\
\hline Kellen K & 3; Mosquito larvae, California \\
\hline Kellen Q & 3; Derived from Kellen $\mathbf{K}$ \\
\hline 1881 & 3; Mosquito larvae, El Salvador \\
\hline 1691 & 3; Mosquito larvae, El Salvador \\
\hline ATCC 7055 & $1,2, B$. fusiformis \\
\hline ATCC 7054 & $1,2, B$. fusiformis \\
\hline ATCC 7063 & $1,2, B$. serositidis \\
\hline ATCC 12300 & 1,2 \\
\hline NRS 718 & 2; Soil, N. R. Smith \\
\hline NRS 1191 & 2,4 \\
\hline NRS 1192 & 2,4 \\
\hline NRS 1194 & 2,4 \\
\hline NRS 1196 & 2,4 \\
\hline NRS 1200 & 2,4 \\
\hline NRS 1201 & $\overrightarrow{2}, \overrightarrow{4}$ \\
\hline NRS 156 & 2; F. Mauer, Army Medical Center, Washington, D.C. \\
\hline NRS 592 & 1,2 \\
\hline NRS 593 & 2; National Institutes of Health \\
\hline NRS 719 & 1,2 \\
\hline NRS 800 & 1,2 \\
\hline NRS 810 & $2 ;$ J. R. Porter, Iowa University \\
\hline NRS 1023 & 2, E. Steinhaus \\
\hline NRS 1187 & 2,4 \\
\hline NRS 1193 & 2,4 \\
\hline NRS 1195 & 2,4 \\
\hline NRS 1197 & 2,4 \\
\hline NRS 1223 & 1,2 \\
\hline NRS 1692 & 2,$5 ;$ T. Gibson, strain 6, B. pycnoticus \\
\hline ATCC 4525 & 1,2 \\
\hline ATCC 4978 & $1,2, B$. rotans \\
\hline ATCC 12123 & 1,2 \\
\hline P1 & D. Tipper, University of Massachusetts \\
\hline NRRL B4297 & L. Nakamura; Peoria, Ill. \\
\hline NRS 400 & 1,2 \\
\hline NRS 717 & 1,2 \\
\hline NRS 1090 & 2; L. Margolena, U.S. Department of Agriculture \\
\hline NRS 1307 & 1,2 \\
\hline NRS 1693 & 2,$5 ;$ T. Gibson, strain $10, B$. pycnoticus \\
\hline ATCC 245 & 1,2 \\
\hline ATCC 13805 & 2 \\
\hline NRS 1198 & 2,4 \\
\hline NRS 1199 & $\overrightarrow{2}, 4$ \\
\hline NRS 1184 & $\overrightarrow{1,2}$ \\
\hline $1537-4 B$ & 3; Mosquito larvae, Nigeria \\
\hline NRS 250 & 1,2 \\
\hline NRS 344 & 2, AMNH741, W. W. Ford \\
\hline NRS 349 & 2 \\
\hline NRS 1089 & 1,2 \\
\hline NRS 1186 & 2,4 \\
\hline NRS 1188 & 2,4 \\
\hline NRS 1611 & 2; L. G. K. Carr from water \\
\hline NRS 1691 & 2, 5; T. Gibson, strain 4, B. pycnoticus \\
\hline NRS 1694 & 2,$5 ;$ T. Gibson, strain $13, B$. pycnoticus \\
\hline
\end{tabular}


TABLE 1-continued

\begin{tabular}{ll}
\multicolumn{1}{c}{ Strain } & \multicolumn{1}{c}{ Source } \\
\hline NRRL B183 & L. Nakamura, Peoria, Ill. \\
NRRL B1876 & L. Nakamura, Peoria, Ill. \\
& \\
B. pasteurii & 1,2 \\
ATCC 11859 & 1,2 \\
NRS 929 & $2 ;$ T. Gibson \\
NRS 673 & 1,2 \\
NRS $674=$ ATCC 6452 & \\
& \\
B. aminovorans & 1,2 \\
NRS $341=$ ATCC 7046 & \\
B. globisporus & 1,2 \\
NRS $1533=$ ATCC 23301 & \\
B. brevis & \\
ATCC 8185 & 1,2 \\
ATCC 8246 & 1,2 \\
ATCC 10027 & 1,2 \\
ATCC 10068 & 1,2 \\
ATCC 11031 & 1,2 \\
NRS 1610 & $2 ;$ M. S. Shane \\
Bacillus sp. & \\
NRS 1513 & 2 \\
NRS 1514 & 2 \\
NRS 1529 & \\
\hline
\end{tabular}

${ }^{a}$ Sources: 1, refer to The Genus Bacillus, Agriculture Handbook 427, U.S. Dept of Agriculture; 2, immediate source, R. Gordon, Rutgers University; 3, immediate source, S. Singer, Western Mlinois University; 4, H. W. Reuszer, Army Deterioration Laboratory; 5, J. R. Norris, Meat Research Institute, Bristol, England.

broth at $30^{\circ} \mathrm{C}$ for $24 \mathrm{~h}$. For DNA isolations, the organisms were grown at $33^{\circ} \mathrm{C}$ in 1 liter of NYSM broth in a 2-liter Erlenmeyer flask. They were shaken at 200 rpm in a New Brunswick model G25 shaker. For bioassays, cells were grown at $33^{\circ} \mathrm{C}$ for $14 \mathrm{~h}$ in $15 \mathrm{ml}$ of NYSM broth in 125-ml Erlenmeyer flasks which were shaken as above.

Cell lysis and DNA isolation. Bacterial cells from one liter of late-logarithmic-phase culture were suspended in $20 \mathrm{ml}$ of distilled water in a $125-\mathrm{ml}$ ground glass-stoppered flask. Lysozyme $(1 \mathrm{mg} / \mathrm{ml})$ was added, and the cells were incubated at $33^{\circ} \mathrm{C}$ for $30 \mathrm{~min}$. Sodium chloride and ethylenediaminetetraacetic acid buffer, $\mathrm{pH} 8.0$ (0.15 and $0.01 \mathrm{M}$ final concentrations), and pancreatic ribonuclease $(50 \mu \mathrm{g} / \mathrm{ml})$ were added, and the cells were lysed by the addition of sodium lauryl sulfate to a final concentration of $1.0 \%$. For those strains of $B$. sphaericus which did not lyse well with the lysozyme and sodium lauryl sulfate treatment, penicillin $\mathrm{G}(0.8 \mathrm{mg} / \mathrm{ml})$ was added to the culture in the late logarithmic phase, and cultivation was continued for $2 \mathrm{~h}$. The cells treated with penicillin lysed well after lysozyme and sodium lauryl sulfate treatment.

DNA was isolated from the lysates by the hydroxylapatite procedure described by Johnson (13). The unlabeled DNA preparations were prepared for the homology experiments by sonicating them at $90 \mathrm{~W}$ for two 30-s time periods with the needle probe of a Virsonic cell disrupter. The DNA preparations were then denatured, and any contaminating ribonucleic acid was hydrolyzed by the addition of $\mathrm{NaOH}$ to a final concentration of $0.25 \mathrm{M}$. The solution was incubated at $50^{\circ} \mathrm{C}$ for $15 \mathrm{~min}$, and samples were cooled in ice and neutralized with $\mathrm{HCl}$. The preparations were dialyzed overnight against $0.02 \mathrm{M} \mathrm{NaCl}-10^{-3} \mathrm{M}$ HEPES ( $N$-2-hydroxyethylpiperazine- $N^{\prime}$-2-ethanesulfonic acid) buffer ( $\mathrm{pH} 7.0$ ). The final concentration of each DNA preparation was adjusted to $0.6 \mathrm{mg} / \mathrm{ml}$ by addition of $0.02 \mathrm{M} \mathrm{NaCl}-10^{-3} \mathrm{M}$ HEPES buffer ( $\mathrm{pH}$ 7.0).

Preparation of labeled DNA. A 10-ml amount of NYSM broth was supplemented with $250 \mu \mathrm{Ci}$ of $\left[{ }^{3} \mathrm{H}\right]$ deoxyadenosine (New England Nuclear Corp.). Bacteria were grown in this broth with shaking for $8 \mathrm{~h}$ at $33^{\circ} \mathrm{C}$. Cells were harvested by centrifugation, and the DNA was isolated by the hydroxylapatite method as previously described. After elution from hydroxylapatite, the DNA was sheared by two passages through a French pressure cell and dialyzed overnight against $0.02 \mathrm{M} \mathrm{NaCl}$. The DNA preparations were alkaline hydrolyzed by the addition of $\mathrm{NaOH}$ to a final concentration of $0.25 \mathrm{M}$ and concentrated by ethanol precipitation; the precipitates were resuspended in $0.02 \mathrm{M}$ $\mathrm{NaCl}-10^{-3} \mathrm{M}$ HEPES buffer, $\mathrm{pH}$ 7.0. The specific activity of the DNA preparations ranged from 7,000 to $22,000 \mathrm{cpm} / \mu \mathrm{g}$.

DNA homology experiments. DNA homology experiments were performed by a variation of the $S 1$ nuclease procedure as described by Crosa et al. (5). 
The reassociation mixtures contained $10 \mu \mathrm{l}(0.1$ or 0.05 $\mu \mathrm{g})$ of labeled DNA, $50 \mu \mathrm{l}(30 \mu \mathrm{g})$ of unlabeled DNA (either homologous, heterologous bacterial, or native fragmented salmon sperm DNA), and $50 \mu \mathrm{l}$ of $0.88 \mathrm{M}$ $\mathrm{NaCl}-10^{-3} \mathrm{M}$ HEPES buffer (pH 7.0). Just before each experiment, the amount of labeled DNA needed for the experiment was denatured by heating in a boiling-water bath for $5 \mathrm{~min}$. Reaction vials containing native salmon sperm DNA were used to measure the amount of self-renaturation of labeled DNA during the incubation period. The reaction vials were incubated for $16 \mathrm{~h}$ at $60^{\circ} \mathrm{C}$.

After incubation, a 100- $\mu$ l sample was removed from each vial and transferred into a $13-$ by $100-\mathrm{mm}$ tube for $\mathrm{S} 1$ nuclease digestion. In addition to the sample of reassociation mixture, each digestion tube contained $1.0 \mathrm{ml}$ of $0.02 \mathrm{M}$ sodium acetate- $0.3 \mathrm{M} \mathrm{NaCl}-0.5 \mathrm{mM}$ $\mathrm{ZnCl}_{2}-5 \%$ glycerol buffer ( $\mathrm{pH} 4.6$ ), $25 \mu \mathrm{g}$ of fragmented, denatured salmon sperm DNA, and $50 \mu \mathrm{l}$ of S1 nuclease (Calbiochem, Behring). The enzyme preparation was diluted such that twice the amount of enzyme was added than was needed to digest totally $30 \mu \mathrm{g}$ of denatured DNA in $1 \mathrm{~h}$. After incubation of the preparation for $1 \mathrm{~h}$ at $50^{\circ} \mathrm{C}$, an equal volume of $10 \%$ trichloroacetic acid was added to each tube. After cooling the preparation in a refrigerator for at least 1 $h$, the precipitates were collected on nitrocellulose filters (BA85, Schleicher and Schuell, Inc.). The membranes were dried, and the radioactivity was measured by means of a liquid scintillation counter and a toluene-based scintillation fluid.

Thermal stability. The extent of base pair mismatching was estimated by determining the thermal stability of heterologous duplexes. The reaction mixtures contained $0.12 \mathrm{ml}$ of labeled DNA $(10 \mu \mathrm{g} / \mathrm{ml})$, $0.6 \mathrm{ml}$ of unlabeled DNA $(0.6 \mathrm{mg} / \mathrm{ml})$, and $0.6 \mathrm{ml}$ of $0.88 \mathrm{M} \mathrm{NaCl}-10^{-3} \mathrm{M}$ HEPES buffer (pH 7.0) in 13 by 100 -mm screw-capped tubes. The mixtures were incubated at $60^{\circ} \mathrm{C}$ for $16 \mathrm{~h}$, and, after cooling, $1.32 \mathrm{ml}$ of $50 \%$ ( $\mathrm{vol} / \mathrm{vol}$ ) formamide was added. The tubes were placed in a water bath at $45^{\circ} \mathrm{C}$, and the temperature was increased in increments of $5^{\circ} \mathrm{C}$ at 10 -min intervals. At the end of each interval, a 200- $\mu$ l sample was removed and placed in a tube for $S 1$ digestion as previously described. The S1-resistant, acid-precipitated DNA was collected by filtration and counted for radioactivity. The cumulative counts up to and including each sample were plotted versus the temperature at which that sample was removed. This resulted in the typical melting point profile. The $T_{m(e)}$ (temperature at which $50 \%$ of the duplexes became $\mathrm{S} 1$ sensitive) was determined from the midpoint of the curve. The $\Delta T_{m(e)}$ 's were calculated by subtracting the $T_{m(e)}$ 's of the heteroduplexes from the $T_{m(e)}$ of the reference strain homoduplexes.

Determination of DNA base composition. The $\mathrm{G}+\mathrm{C}$ contents of the DNA preparations were calculated from their thermal melting points $\left(T_{m}\right)$ by means of the method of Marmur and Doty (17). Escherichia coli B DNA served as the standard.

Phenotypic tests. With the exceptions described below, phenotypic tests were carried out by the methods of Gordon et al. (10). Urease activity was determined with the medium described by Christensen (4) supplemented with $0.05 \% \mathrm{wt} / \mathrm{vol}$ ) yeast extract (Difco) and also by the method described by Gordon et al. (11). Deamination of phenylalanine was tested by pipetting 4 or 5 drops of $10 \%(w t / v o l) \mathrm{FeCl}_{3}$ over cultures grown 7 to 21 days on phenylalanine (Difco) agar slants. A greenish coloration of the agar indicated formation of phenylpyruvic acid from phenylalanine. The oxidase test was performed by placing a moistened test disk (Difco) on a colony grown on NYSM agar for $48 \mathrm{~h}$. Oxidase was present if the colony turned red to purple. For the detection of catalase, 4 to 5 drops of $3 \% \mathrm{H}_{2} \mathrm{O}_{2}$ were added to 24- to 48-h-old NYSM broth cultures, and the appearance of bubbles was observed. All strains were examined for motility by phase-contrast observation of a drop of 24-h-old NYSM broth culture. Acetylmethylcarbinol production was tested by adding $0.5 \mathrm{ml}$ of $\alpha$-naphthol solution (5\%, wt/vol, in ethanol) and $0.5 \mathrm{ml}$ of $40 \%(\mathrm{wt} / \mathrm{vol})$ $\mathrm{KOH}$ to cultures grown for 14 days in MR.VP broth (Difco). Tubes were allowed to stand for $30 \mathrm{~min}$, and the appearance of a red color indicated formation of acetylmethylcarbinol. Three drops of alcoholic methyl red were added to duplicate tubes, and acid production was indicated by a red color. Aerobic reduction of nitrate was tested by adding sulfanilic acid and $\alpha$ naphthylamine to a culture of nitrate broth (Difco) supplemented with $0.05 \%$ (wt/vol) yeast extract (Difco). A pink to red color indicated the presence of nitrite. Zinc powder was added to those tubes which were negative to detect possible reduction beyond nitrite. Casein hydrolysis within 10 days was detected by a clearing around the colony on NYSM agar (Difco) plates containing $10 \%$ (wt/vol) skim milk (Difco). A similar clearing was observed on plates supplemented with $2.0 \%$ (wt/vol) corn starch if amylase was present. Gelatin hydrolysis was tested by growing cultures in tubes of NYSM broth containing 12\% (wt/vol) gelatin.

Bioassays. Pathogenicity for second instar larvae of the mosquito Culex pipiens quinquefasciatus was determined as previously described (18). Strains were judged to be pathogenic if larval death greater than control death occurred when larvae were incubated with approximately $10^{8}$ bacteria per $\mathrm{ml}$ for 4 days.

\section{RESULTS}

$G+C$ content of the DNA. The $\mathrm{G}+\mathrm{C}$ contents of the DNAs from most of the strains used in this study are given in Tables 2 and 4 . These values ranged from 34 to $37 \mathrm{~mol} \%$, with the majority of strains at 35 or $36 \mathrm{~mol} \%$. The strains of $B$. pasteurii and $B$. aminovorans had $\mathrm{G}+\mathrm{C}$ values in the same range and could not be distinguished from $B$. sphaericus on this basis. $B$. brevis, a species forming an elliptical spore but having somewhat similar metabolic reactions to those of $B$. sphaericus, had higher $\mathrm{G}+\mathrm{C}$ values: 46 or $47 \%$ (three strains) to 52 to $55 \%$ (three strains). The apparent heterogeneity among the $B$. brevis strains was not investigated further, but these strains were readily distinguishable from those of $B$. sphaericus.

DNA homologies among strains of $B$. sphaericus. When DNA homologies were de- 
TABLE 2. B. sphaericus DNA homology groups

\begin{tabular}{|c|c|c|c|c|c|c|c|c|}
\hline \multirow[b]{2}{*}{$\begin{array}{l}\text { Unlabeled } \\
\text { DNA from } \\
\text { strain }\end{array}$} & \multirow[b]{2}{*}{$\begin{array}{c}\mathrm{G}+\mathrm{C} \\
\text { content } \\
\text { of DNA } \\
(\mathrm{mol} \%)\end{array}$} & \multicolumn{7}{|c|}{ \% Homology to DNA of reference strains } \\
\hline & & $\begin{array}{l}\text { ATCC } \\
14577\end{array}$ & 1593 & $\begin{array}{c}\text { ATCC } \\
7055\end{array}$ & $\begin{array}{c}\text { NRS } \\
592\end{array}$ & $\begin{array}{c}\text { NRS } \\
400\end{array}$ & $\begin{array}{l}\text { NRS } \\
1198\end{array}$ & $\begin{array}{c}\text { P. pas- } \\
\text { teurii } \\
\text { ATCC } \\
11859 \\
\end{array}$ \\
\hline \multicolumn{9}{|l|}{ Group I } \\
\hline $\operatorname{ATCC} 14577^{a}$ & 36 & 100 & 23 & 20 & 22 & 22 & 20 & 6 \\
\hline ATCC 10208 & 36 & 91 & 25 & 21 & 21 & 23 & 17 & 3 \\
\hline NRS 967 & 36 & 89 & 25 & 17 & 16 & 13 & 10 & 4 \\
\hline NCTC 9602 & 36 & 77 & 25 & 20 & 21 & 20 & 21 & 3 \\
\hline \multicolumn{9}{|l|}{ Group IIA } \\
\hline 1593 & 35 & 19 & 100 & 60 & 40 & 47 & 24 & 2 \\
\hline SSII-1 & 35 & 20 & 83 & 60 & 40 & 47 & 23 & 4 \\
\hline $1404-924 \mathrm{~B}$ & 35 & 19 & 86 & 57 & 37 & $\mathrm{ND}^{b}$ & 20 & 4 \\
\hline Kellen K & 35 & 19 & 82 & 59 & 40 & 43 & 21 & 3 \\
\hline Kellen Q & 35 & 19 & 79 & 61 & 41 & ND & 24 & 2 \\
\hline 1881 & ND & 19 & 88 & 64 & 38 & ND & 23 & ND \\
\hline 1691 & ND & 19 & 80 & 60 & 37 & 41 & 24 & ND \\
\hline \multicolumn{9}{|l|}{ Group IIB } \\
\hline ATCC 7055 & 36 & 16 & 64 & 100 & 43 & 43 & 22 & 4 \\
\hline ATCC 7054 & ND & 23 & 63 & 93 & 43 & ND & 21 & ND \\
\hline ATCC 12300 & 35 & 21 & 66 & 93 & 37 & ND & 20 & ND \\
\hline NRS 718 & 36 & 17 & 62 & 81 & 38 & 38 & $\mathrm{ND}$ & 4 \\
\hline NRS 1191 & 36 & 18 & 66 & 78 & 40 & ND & 20 & 2 \\
\hline NRS 1196 & 36 & 14 & 62 & 76 & 41 & 50 & 22 & 1 \\
\hline ATCC 7063 & 35 & 21 & 62 & 76 & 39 & ND & ND & 5 \\
\hline NRS 1194 & 36 & 21 & 60 & 75 & 42 & ND & 26 & 2 \\
\hline NRS 1200 & 35 & 20 & 64 & 74 & 43 & 46 & 30 & 6 \\
\hline NRS 1201 & 35 & 17 & 63 & 72 & 38 & ND & ND & ND \\
\hline NRS 1192 & 36 & 18 & 62 & 69 & 39 & 43 & ND & 4 \\
\hline NRS 156 & 35 & 14 & 63 & 68 & 41 & 45 & 21 & 2 \\
\hline \multicolumn{9}{|l|}{ Group III } \\
\hline NRS 592 & 36 & 18 & 42 & 44 & 100 & 52 & 24 & 5 \\
\hline ATCC 12123 & 35 & 21 & 37 & 36 & 88 & 56 & 26 & ND \\
\hline $\mathrm{P} 1$ & 36 & 19 & 41 & 35 & 88 & 54 & ND & 4 \\
\hline NRS 800 & 35 & 16 & 41 & 34 & 86 & 54 & 21 & 3 \\
\hline NRS 1692 & ND & 23 & 37 & ND & 84 & ND & ND & ND \\
\hline NRS 593 & 36 & 18 & 35 & 32 & 83 & 43 & 19 & 4 \\
\hline NRS 1195 & 35 & 22 & 41 & 37 & 83 & ND & ND & 2 \\
\hline NRS 1193 & 34 & 18 & 43 & 33 & 81 & 55 & ND & 2 \\
\hline NRS 1197 & 36 & 17 & 42 & 36 & 80 & 51 & ND & 4 \\
\hline NRS 1187 & 35 & 17 & 42 & 47 & 79 & 61 & 45 & 2 \\
\hline NRS 1023 & 35 & 18 & 34 & 42 & 78 & 62 & 27 & ND \\
\hline NRRL B4297 & 35 & 18 & 43 & 41 & 79 & 64 & 32 & 3 \\
\hline NRS 810 & 35 & 21 & 41 & 36 & 77 & 64 & 21 & ND \\
\hline NRS 719 & 35 & 18 & 41 & 43 & 76 & 55 & 0 & 5 \\
\hline ATCC 4525 & 35 & 23 & 38 & 37 & 76 & 57 & 26 & ND \\
\hline \multicolumn{9}{|l|}{ Group III } \\
\hline ATCC $4978^{\circ}$ & 36 & 19 & 39 & 29 & 70 & 64 & 25 & ND \\
\hline NRS 1223 & 36 & 20 & 36 & 45 & 63 & 56 & 23 & ND \\
\hline \multicolumn{9}{|l|}{ Group IV } \\
\hline NRS 400 & 36 & 18 & 41 & 37 & 43 & 100 & 24 & ND \\
\hline NRS 717 & 37 & 18 & 40 & 37 & 49 & 100 & 23 & 4 \\
\hline NRS $1529^{d}$ & ND & 23 & 42 & 37 & 47 & 98 & 9 & ND \\
\hline ATCC 13805 & 35 & 18 & 38 & 32 & 50 & 97 & 25 & 5 \\
\hline ATCC 245 & 36 & 21 & 39 & 39 & 48 & 94 & 23 & ND \\
\hline NRS 1090 & 36 & 16 & 45 & 41 & 41 & 93 & 22 & 3 \\
\hline NRS 1693 & ND & 22 & 43 & ND & 52 & 86 & ND & ND \\
\hline NRS 1307 & 37 & 19 & 41 & 41 & 63 & 66 & 38 & ND \\
\hline
\end{tabular}


TABLE 2-continued

\begin{tabular}{|c|c|c|c|c|c|c|c|c|}
\hline \multirow[b]{2}{*}{$\begin{array}{l}\text { Unlabeled } \\
\text { DNA from } \\
\text { strain }\end{array}$} & \multirow[b]{2}{*}{$\begin{array}{c}\mathrm{G}+\mathrm{C} \\
\text { content } \\
\text { of DNA } \\
(\mathrm{mol} \%)\end{array}$} & \multicolumn{7}{|c|}{ \% Homology to DNA of reference strains } \\
\hline & & $\begin{array}{c}\text { ATCC } \\
14577\end{array}$ & 1593 & $\begin{array}{c}\text { ATCC } \\
7055\end{array}$ & $\begin{array}{c}\text { NRS } \\
592\end{array}$ & $\begin{array}{c}\text { NRS } \\
400\end{array}$ & $\begin{array}{l}\text { NRS } \\
1198\end{array}$ & $\begin{array}{c}\text { B. pas- } \\
\text { teurii } \\
\text { ATCC } \\
11859\end{array}$ \\
\hline \multicolumn{9}{|l|}{ Group V } \\
\hline NRS 1198 & 35 & 20 & 24 & 24 & 30 & 30 & 100 & 6 \\
\hline NRS 1199 & 35 & 23 & 13 & 28 & 27 & 32 & 80 & 4 \\
\hline NRS 1184 & 35 & 25 & 13 & 26 & 24 & ND & 74 & ND \\
\hline \multicolumn{9}{|c|}{ Ungrouped Strains } \\
\hline $1537-4 \mathrm{~B}$ & ND & 25 & 25 & ND & 30 & ND & 54 & ND \\
\hline NRS 1186 & 36 & 21 & 27 & 22 & 25 & 31 & 48 & 2 \\
\hline NRRL B1876 & 35 & 22 & 32 & ND & 24 & ND & 47 & NL. \\
\hline NRS 1089 & 36 & 23 & 24 & $\mathrm{ND}$ & 23 & ND & 43 & $\mathrm{ND}$ \\
\hline NRS $1533^{e}$ & ND & 25 & 24 & 4 & 32 & 6 & 42 & ND \\
\hline NRS 250 & 34 & 21 & 24 & 22 & 29 & 50 & 33 & 1 \\
\hline NRS 1611 & 34 & 20 & 32 & 20 & 26 & 41 & 33 & 2 \\
\hline NRRL B183 & 36 & 30 & 26 & ND & 20 & ND & 15 & ND \\
\hline NRS 344 & 35 & 15 & 38 & 36 & 32 & 39 & 18 & ND \\
\hline NRS 1188 & 36 & 4 & 4 & 4 & 5 & 7 & 6 & 2 \\
\hline NRS 1694 & 34 & 7 & 8 & ND & 8 & ND & 4 & 5 \\
\hline NRS 1691 & ND & 7 & 6 & ND & 10 & ND & 7 & ND \\
\hline NRS 349 & ND & 8 & 7 & 8 & 10 & 18 & 4 & ND \\
\hline NRS $341^{f}$ & 36 & 7 & 8 & ND & 5 & ND & 3 & 3 \\
\hline NRS 1513 & ND & 3 & 9 & ND & 4 & ND & 2 & 3 \\
\hline NRS 1514 & ND & 3 & 7 & ND & 6 & ND & 3 & ND \\
\hline
\end{tabular}

${ }^{a}$ Type strain.

${ }^{b} \mathrm{ND}$, Not determined.

${ }^{c} B$. rotans.

${ }^{d} B$. species.

${ }^{e} B$. globisporus.

${ }^{f} B$. aminovorans.

termined, a considerable amount of heterogeneity was found among the strains previously identified as B. sphaericus. Five distinct DNA homology groups have been identified, and one of these, group II, has been divided into two subgroups. Sixteen additional strains did not fit into any of the homology groups, although in some cases their homology relationships are incomplete (Table 2).

DNA homology group I (Table 2) represents the species $B$. sphaericus since it includes ATCC 14577 , the type strain of the species. Only three other strains showed a high percentage of homology to this reference strain.

DNA homology group II (Table 2) was divided into two subgroups, with reference strains 1593 (group IIA) and ATCC 7055 (group IIB). Subgroup IIA was clearly distinguishable from subgroup IIB, since all strains of IIA had $79 \%$ or greater homology to strain 1593 but no greater than $64 \%$ homology to the IIB reference strain ATCC 7055. The strains placed in IIB had homologies ranging down to $68 \%$ for ATCC 7055 while having homologies up to $66 \%$ for the group IIA reference strain 1593. The grouping of strains NRS 1192 and NRS 156 was somewhat equivocal. This problem was resolved by determinating the difference in thermal stability of homologous and heterologous duplexes $T_{m(e)}$ for the questionable strains (Table 3). The $\Delta T_{m(e)}$ of the heteroduplexes formed between DNA preparations from strains of the two homology subgroups had values that ranged between 6.7 and $7.5^{\circ} \mathrm{C}$ while the $\Delta T_{m(e)}$ for heteroduplexes within a subgroup was no greater than $2.5^{\circ} \mathrm{C}$ ('Table 3 ). These results indicated a significant difference in the arrangement of nucleotides between the strains of the two subgroups. Subgroup IIA could be readily distinguished from subgroup IIB and from all other homology groups by the fact that only the seven strains belonging to this subgroup were found to be pathogenic for mosquito larvae.

The largest of the DNA homology groups was group III (Table 2). This group contained 17 strains of $B$. sphaericus. Homology values within this group ranged from 88 down to $63 \%$. This group is closely related to group IV in that the DNA preparations had an average homology of $57 \%$ to the group IV reference strain, NRS 400 . B. rotans, described by Roberts $(20)$ as a strain of Bacillus having mobile colonies, was 
found to belong to this group.

DNA homology group IV (Table 2) contained seven strains with high homology to the reference strain NRS 400. Strain NRS 1529 had previously been identified merely as Bacillus sp. Strain NRS 1307 was placed in homology group IV because of its slightly higher homology to NRS 400 than to NRS 592.

Homology group $\mathrm{V}$ was the smallest of those identified, and it contained only three strains (Table 2). The four strains of $B$. pasteurii examined comprised a very homogeneous homology group having little homology to any of the B. sphaericus reference strains (Table 4). None of the $B$. sphaericus strains showed homology to the $B$. pasteurii reference strain, ATCC 11859. The DNA from six strains of $B$. brevis was tested for homology to the DNA from the reference strains for homology groups I, IIA, and III and the $B$. pastreurii group. Little homology was detected, as would have been predicted from the different $\mathrm{G}+\mathrm{C}$ values found for these bacteria.

Phenotypic characteristics. A limited number of tests for physiological characteristics was carried out in an attempt to separate the

TABLE 3. Thermal stability of DNA heteroduplexes constructed between group II strains

\begin{tabular}{lll}
\hline & \multicolumn{2}{c}{$\Delta T_{m(e)}$ of DNA duplexes } \\
\cline { 2 - 3 } Strain & & \multicolumn{1}{c}{ ATCC } \\
& 1593 & 7055 \\
\hline Group IIA & & \\
1593 & 0 & ND $^{a}$ \\
SSII-1 & 0.7 & 6.7 \\
1881 & 0.7 & ND \\
Group IIB & & \\
ATCC 7055 & 7.2 & 0 \\
ATCC 12300 & ND & 0 \\
NRS 718 & 7.45 & 0.75 \\
NRS 1200 & 7.5 & 2.0 \\
NRS 156 & 7.0 & 2.3 \\
NRS 1192 & 7.0 & 2.25 \\
NRS 1194 & ND & 1.8 \\
NRS 1196 & ND & 2.5 \\
\hline
\end{tabular}

${ }^{a} \mathrm{ND}$, Not determined.
DNA homology groups. The data summarized in Table 5 indicate that no group of phenotypic traits allowed complete separation of all the homology groups. Group I was distinguishable from groups IIA and IIB by its utilization of citrate and by its failure to produce urease or to grow in broth supplemented with $7 \% \mathrm{NaCl}$. Group IIA was distinguishable from all other groups in that it contained strains which were pathogenic for mosquito larvae. The other characteristics examined were either constant among all the strains or were variable among the members of the homology groups. Five strains of $B$. pasteurii (the four listed in Table 4 as well as NRS 675) failed to grow on NYSM agar unless this was supplemented with urea, and thus they were readily distinguishable from all of the strains of $B$. sphaericus which grew on unsupplemented NYSM agar.

\section{DISCUSSION}

The genetic heterogeneity found among the strains of $B$. sphaericus studied is not particularly surprising in view of the phenotypic variation which has been described for this species. Also, Seki et al. (21) had observed that only one of four strains of $B$. sphaericus which they examined had high DNA homology to the type strain of the species. We found only three strains to have high homology with the type strain ATCC 14577 (homology group I). This group appears to be less related to the other homology groups than the other groups are to each other. Strains from the other $B$. sphaericus groups had homologies ranging from 14 to $26 \%$ to the type strain.

Homology group IIA-IIB contains strains which are phenotypically very similar (Table 5) and which bear a definite genetic relationship. Nonetheless, there is an easily recognizable gap in percent homology between most of the strains of subgroups IIA and IIB. The two strains which were in a questionable position, NRS 1192 and NRS 156, were confirmed in their IIB position by the determination of the thermal stability of their DNA heteroduplexes. The bacteria in

TABLE 4. B. pasteurii DNA homology group

\begin{tabular}{|c|c|c|c|c|c|c|c|c|}
\hline \multirow[b]{2}{*}{$\begin{array}{c}\text { Unlabeled } \\
\text { DNA from } \\
\text { strain }\end{array}$} & \multirow[b]{2}{*}{$\begin{array}{c}\mathrm{G}+\mathrm{C} \\
\text { content } \\
\text { of DNA } \\
(\mathrm{mol} \%)\end{array}$} & \multicolumn{7}{|c|}{$\%$ Homology to DNA of reference strains: } \\
\hline & & $\begin{array}{c}\text { ATCC } \\
14577\end{array}$ & 1593 & $\begin{array}{c}\text { ATCC } \\
7055\end{array}$ & $\begin{array}{c}\text { NRS } \\
592\end{array}$ & $\begin{array}{c}\text { NRS } \\
400\end{array}$ & $\begin{array}{c}\text { NRS } \\
1198\end{array}$ & $\begin{array}{c}\text { B. pas- } \\
\text { teurii } \\
\text { ATCC } \\
11859\end{array}$ \\
\hline ATCC $11859^{a}$ & 37 & 2 & 6 & 0 & 2 & 0 & 0 & 100 \\
\hline NRS 929 & 37 & 0 & 6 & 0 & 3 & 4 & $\mathrm{ND}^{b}$ & 99 \\
\hline NRS 673 & 37 & 2 & 5 & 7 & 2 & 4 & ND & 94 \\
\hline NRS 674 & 37 & 0 & 2 & $\mathrm{ND}$ & 3 & ND & $\mathrm{ND}$ & 97 \\
\hline
\end{tabular}

\footnotetext{
"Type strain.
}

${ }^{b}$ ND, Not determined. 
TABLE 5. Physiological characteristics of the DNA homology groups

\begin{tabular}{|c|c|c|c|c|c|c|}
\hline \multirow[b]{2}{*}{ Trait } & \multicolumn{6}{|c|}{ \% of strains positive } \\
\hline & $\underset{\text { G }}{\text { Group }}$ & Group & $\begin{array}{l}\text { Group } \\
\text { IIB }\end{array}$ & $\begin{array}{l}\text { Group } \\
\text { III }\end{array}$ & $\begin{array}{l}\text { Group } \\
\text { IV }\end{array}$ & $\underset{\mathrm{V}}{\text { Group }}$ \\
\hline Mosquito pathogenicity & 0 & 100 & 0 & 0 & 0 & 0 \\
\hline Urease production & 0 & 100 & $92^{a}$ & $61^{a}$ & 0 & $66^{a}$ \\
\hline Utilization of citrate & 100 & 0 & 0 & $22^{b}$ & $57^{c}$ & 0 \\
\hline Growth with $7 \% \mathrm{NaCl}$ present & 0 & 100 & 100 & $78^{d}$ & $71^{d}$ & $66^{d}$ \\
\hline Casein hydrolysis & $75^{e}$ & 100 & $83^{e}$ & $23^{f}$ & $71^{e}$ & 100 \\
\hline Gelatin liquefaction & 100 & 100 & $92^{8}$ & $89^{8}$ & 100 & 100 \\
\hline $\begin{array}{l}\text { Oxidase, motility, catalase, growth in presence of } 5 \% \\
\mathrm{NaCL}\end{array}$ & 100 & 100 & 100 & 100 & 100 & 100 \\
\hline $\begin{array}{l}\text { Amylase, nitrate reduction, methyl red-Voges-Proskauer } \\
\text { test, indole, utilization of L-tyrosine, growth with } 10 \% \\
\mathrm{NaCl} \text { present, acid production from glucose or lactose }\end{array}$ & 0 & 0 & 0 & $\mathbf{0}$ & 0 & 0 \\
\hline Deamination of phenylalanine & 100 & 100 & $66^{h}$ & $89^{h}$ & $86^{h}$ & $100_{1}:$ \\
\hline Growth with lysozyme present $(10 \mu \mathrm{g} / \mathrm{ml})$ & $25^{i}$ & 100 & $75^{j}$ & $6^{i}$ & $28^{i}$ & $33^{i}$ \\
\hline
\end{tabular}

${ }^{a}$ Negative strains-IIB: ATCC 7063; III: NRS 1187, 810, 719, 4525, 4978, 1223, NRRL 4297; V: 1184.

${ }^{b}$ Positive strains-NRS 592, 593, 1023, 1197.

c Negative strains-NRS 400, 717, 1529.

${ }^{d}$ Negative strains-III: NRS 1692, 4525, 1307, 1223; IV: NRS 245, 1693; V: NRS 1198.

e Negative strains-I: NRS 9602; IBB: NRS 1191, ATCC 7063; IV: NRS 717, 1529.

${ }^{f}$ Positive strains-NRS 1193, 810, 719, 1307.

${ }^{g}$ Negative strains-IIB: ATCC 7063; III: NRS 810, 719.

${ }^{h}$ Negative strains-IIB: NRS 718, 1196, ATCC 7054, 7063; III: NRS 1187, 719; IV: NRS 400.

${ }^{i}$ Positive strains-I: ATCC 14577; III: NRS 1023; IV: ATCC 245, NRS 1090; V: NRS 1198.

${ }^{j}$ Negative strains-IIB: NRS 1191, 156, ATCC 7063.

group IIA are particularly interesting since all seven strains were shown to be pathogenic for mosquito larvae, a trait not possessed by the strains in group IIB. The IIA strains have been shown to be pathogenic by virtue of a cell-bound toxin of unidentified composition (18). All of the mosquito pathogens had been isolated from dead mosquito larvae (22), although nonpathogenic strains are also occasionally isolated from this source (S. Singer, personal communication). Since none of the strains which were obtained from other sources was a mosquito pathogen, it is possible that the conditions present in the mosquito larval gut represent a unique habitat suitable to the development and successful maintenance of these pathogens. Strain ATCC 7063 ( $B$. serositidis), a human clinical isolate (16), was placed in group IIB. It was not closely related to NRS 592, which was also of clinical origin. ATCC 7063, NRS 592, and NRS 593, another isolate of clinical origin, did not demonstrate pathogenicity by subcutaneous injection of mice or by intraperitoneal or intracerebral injection of rats (John Shadduck, personal communication).

The largest number of the strains studied belong to homology group III, with reference strain NRS 592. The placement of ATCC 4978 into this group confirms the judgment of Gordon et al. (10) that this strain, originally called $B$. rotans, is related to $B$. sphaericus. Homology groups III and IV are closely related. In the lower range of homologies within each group, it becomes difficult to distinguish the group to which the strains belong. We have assigned these strains simply on the basis of the highest homology values. Perhaps these strains, e.g., ATCC 4978, NRS 1223, and NRS 1307, constitute an additional homology group. This could be determined by using one of them as a reference strain.

Twelve strains of $B$. sphaericus could not be placed into any of the five homology groups based upon the data available. Four of these strains-NRS 1188, 1694, 1691, and 349-had so little relationship to any of the reference strains that it would seem advisable to review their phenotypic properties. These strains may be more closely related to another species. The type strain of B. globisporus, NRS 1533, had $42 \%$ homology to the group V reference strain, NRS 1198. B. globisporus 1533 grew well at $22^{\circ} \mathrm{C}$ but failed to grow at $32^{\circ} \mathrm{C}$ in contrast to the $B$. sphaericus strains which grew well at the higher temperature. The type strain of $B$. aminovorans, NRS 341, showed no relationship to $B$. sphaericus.

None of the $B$. sphaericus strains for which data were obtained showed any relationship to the type strain of $B$. pasteurii, ATCC 11859. The strains of $B$. pasteurii were unable to grow in NYSM broth without the addition of urea, 
and the four strains examined in this study were genetically very homogenous. Despite certain similarities to $B$. sphaericus, there should be no doubt that these strains constitute a distinct species.

The DNA from $B$. brevis showed little homology to those $B$. sphaericus groups to which it was compared or to the DNA of B. pasteurii. These bacteria also appear to constitute a distinct species.

The phenotypic characteristics determined in this study were not adequate to allow the placement of a specific $B$. sphaericus strain into the appropriate homology group. The only exception to this conclusion is that pathogenicity for mosquito larvae is a property possessed exclusively by members of homology group IIA. Unfortunately, the chemical nature of the toxin(s) responsible for this pathogenicity and the genetic stability of the toxin(s) have not yet been sufficiently well studied for us to recommend the use of this trait as the basis for the establishment of a new species. Each of the homology groups identified in this study contains strains having a sufficiently high level of genetic relatedness to justify speciation (12). However, the present inability to distinguish these strains by readily determined phenotypic tests suggests that it would be premature to propose the establishment of new species. We propose, therefore, that these bacteria continue to be named $B$. sphaericus, at the same time recognizing that they represent genetically distinctive groups.

\section{ACKNOWLEDGMENTS}

This investigation received support from the Vector Biology and Control component of the VNDP/World Bank/World Health Organization Special Programme for Research and Training in Tropical Diseases. We thank Ruth Gordon for her contribution of cultures and for her advice.

\section{REPRINT REQUESTS}

Address reprint requests to: A. Yousten, Microbiology Section, Biology Department, Virginia Polytechnic Institute, Blacksburg, VA 24061.

\section{LITERATURE CITED}

1. Allen, B., and H. Wilkinson. 1969. A case of meningitis and generalized Shwartzman reaction caused by Bacillus sphaericus. Johns Hopkins J. 125:8-13.

2. Bornside, E. H., and R. E. Kallio. 1956. Urea-hydrolyzing bacilli. I. A physiological approach to identification. J. Bacteriol. 71:627-634.

3. Bornside, E. H., and R. E. Kallio. 1956. Urea-hydrolyzing bacilli. II. Nutritional profiles. J. Bacteriol. 71:655660 .

4. Christensen, W. B. 1946 . Urea decomposition as a means of differentiating Proteus and paracolon cultures from each other and from Salmonella and Shigella types. J. Bacteriol. 52:461-466.

5. Crosa, J., D. Brenner, and S. Falkow. 1973. Use of a single-strand specific nuclease for analysis of bacterial and plasmid deoxyribonucleic acid homo- and heteroduplexes. J. Bacteriol. 115:904-911.

6. deBarjac, H., and A. Bonnefoi. 1972. Essai de classification biochimique de 64 Bacillus des groupes II et III representant II especes differentes. Ann. Inst. Pasteur. 122:463-473.

7. Farrar, W. 1963. Serious infections due to non-pathogenic organisms of the genus Bacillus. Am. J. Med. 34:134141.

8. Gibson, T. 1935. An investigation of the Bacillus pasteurii group. III. Systematic relationships of the group. J. Bacteriol. 29:491-501.

9. Gibson, T., and R. E. Gordon. 1974. Endospore-forming rods and cocci. Family I. Bacillaceae, genus I. Bacillus (Cohn, p. 529-550. In R. E. Buchanan and N. E. Gibbons (ed.), Bergey's manual of determinative bacteriology, 8th ed. The Williams and Wilkins Co., Baltimore.

10. Gordon, R. E., W. C. Haynes, and C. Hov-Nay Pang. 1973. The genus Bacillus. Agricultural handbook no. 427. U.S. Department of Agriculture, Washington, D.C.

11. Gordon, R. E., J. Hyde, and J. Moore. 1977. Bacillus firmus-Bacillus lentus: a series or one species? Int. J. Syst. Bacteriol. 27:256-262.

12. Johnson, J. L. 1973. Use of nucleic-acid homologies in the taxonomy of anaerobic bacteria. Int. J. Syst. Bacteriol. 23:359-375.

13. Johnson, J. L. 1978. Taxonomy of the Bacteroides. I. Deoxyribonucleic acid homologies among Bacteroides fragilis and other saccharolytic Bacteroides species. Int. J. Syst. Bacteriol. 29:245-256.

14. Kellen, W., T. Clark, J. Lindengren, B. Ho, M. Rogoff, and S. Singer. 1965. Bacillus sphaericus Neide as a pathogen of mosquitoes. J. Invertebr. Pathol. 7:442448.

15. Knight, B. C. J. G., and H. Proom. 1950. A comparative survey of the nutrition and physiology of mesophilic species in the genus Bacillus. J. Gen. Microbiol. 4:508538.

16. LaCorte, J. 1932. Bacillus serositidis, nova especie. Mem. Inst. Oswaldo Cruz Rio de Janeiro. 26:1-7.

17. Marmur, J., and P. Doty. 1962. Determination of the base composition of deoxyribonucleic acid from its thermal denaturation temperature. J. Mol. Biol. 5:109-118.

18. Myers, P., and A. Yousten. 1978. Toxic activity of Bacillus sphaericus SSII-1 for mosquito larvae. Infect. Immun. 19:1047-1053.

19. Neide, E. 1904. Botanische Beschreibung einiger sporenbildenden Bacterien. Zentralbl. Bacteriol. Parasitenk. Infektionskr. Hyg. Abt. 2 12:1-32.

20. Roberts, J. L. 1935. A new species of the genus Bacillus exhibiting mobile colonies on the surface of nutrient agar. J. Bacteriol. 29:229-236.

21. Seki, T., C.-K. Chung, H. Mikami, and Y. Oshima. 1978. Deoxyribonucleic acid homology and taxonomy of the genus Bacillus. Int. J. Syst. Bacteriol. 28:182-189.

22. Singer, S. 1973. Insecticidal activity of recent bacterial isolates and their toxins against mosquito larvae. $\mathrm{Na}$ ture (London) 244:110-111.

23. Smith, N. R., R. E. Gordon, and J. B. Clark. 1952. Aerobic sporeforming bacteria. Agriculture monograph no. 16. U.S. Department of Agriculture, Washington, D.C. 